matic colours which it had in the north disappear, and the whole mass, except under peculiar circumstances, looks like a motuntain of soda. At rare intervals, however, during a gorgeous sunset, the tinted clouds are reflected on its sides, and their various colours flash across like the shades of a rich shot silk, but infinitely more beautiful, eliciting terms of admiration alike from the sentimental dandy or the rough emigrant.

The cause of their early appearance so far south this spring is a mystery; many attribute it to a mild season. As I have before stated, I cannot concur in this opinion. No man can with certainty assert that in the Arctic regions a January temperature can cause the fracture of such masses from their original beds.

Celtic, July 28 WM. W. KIDDLE

\section{Science at Cambridge}

IN an article on the Public Schools Commission published in NATURE (vol. x. p. 219), the following passage occurs :- "Now it is acknowledged on all hands that the teaching of a subject at school and its recognition at the universities are inseparably connected, and especially with regard to science. The Colleges say, We cannot give more scholarships, because a sufficient number of men of good attainments do not present themselves; and the Schools reply, We cannot spend our time on subjects for which there are so few rewards. Both profess willingness, but each calls on the other to take the initiative." It is implied by this that the schools and universities each shelter themselves in their conservatism by throwing the blame on the other. With respect to the University of Cambridge, at least, I think this is unfair. King's College offered scholarships (of $80 \%$. a year for three years) for natural or physical science in the years 1872 and 1873 ; on both occasions the examiners (who were in no way connected with the college) reported that no candidates of sufficient merit had presented themselves. At length, in the present year, they have awarded a scholarship in these subjects.

Everyone who is conversant with Cambridge knows that the colleges are anxious to reward proficiency in science, and that the tendency is distinctly to award scholarships therein on easier terms than in other subjects, but that there is a dearth of candidates. Although the valuable science scholarships at Trinity have always been open to members of all colleges of either university, the number of those who have tried has always been very small.

I maintain, then, that Cambridge has taken the initiative as far as it is desirable to do so. It would be a lamentable thing to award prizes too profusely, as we should thereby be stocking the University with an inferior staff of teachers, who would transmit their inferiority to the succeeding generation.

Trinity College, Cambridge, July 30 GEORGE DARWIN

\section{Circulation of Apparatus and Scientific Works}

The letter of $\mathrm{Mr} . \mathrm{H}$. W. Lloyd Tanner (NATURE, vol. $\mathrm{x}$. p. 244) has opened up a subject of importance to all science teachers, and surely there are no insuperable difficulties in the way of the Kensington authorities sending out for loan, under proper conditions, apparatus and scientific works. Already there are loan collections of apparatus to be obtained from South Ken. sington by any recognised science class, but the cost of getting up and sending them out must be far greater than necessary. We were much amused last winter by receiving from the Department of Science and Art, as a loan, five huge boxes of elementary chemical apparatus. When these were opened we were quite disappointed, for only a few pieces proved useful in our class. We did not want a lot of big bell jars, glass retorts, Florence flasks, and bits of glass tubing stuck through wretched corks. Anyone can easily understand that it is simply waste of money to send to a science class apparatus on loan that the class already possesses. Why are not teachers allowed to choose the apparatus? In furtherance of the object mentioned by Mr. Tanner, may I be allowed to offer the following suggestions :-

I. That a collection of scientific apparatus and standard works for loan be made at Kensington.

2. That science teachers desirous of using books and apparalus pay a subscription, say, of ros. per annum.

3. That lists of apparatus and books be published, and sold to subscribers at a reasonable figure.

4. That books and apparatus (from list) be lent for a term to subscribers (subject, of course, to conditions of return in good order).
5. That the Department pay the carriage to and from Kensington.

Perhaps other readers of NATURE will kindly give further suggestions.

To such as myself, anything like the above would be a boon indeed. Living in a small country town in which there is neither public reading.room nor library, and being daily engaged in teaching science, and, withal, intensely fond of the study of it, I am thrown almost entirely upon my own resources to provide scientific books and apparatus. Yet I am better off than numbers of science teachers. The trustees of our schools have lately granted 57. a year for scientific apparatus, and to this we get the Government grant of 50 per cent. added. Further, I can at any time borrow a good microscope, and have access to several private libraries belonging to gentlemen of scientific tastes. Still, frequently, the very information wanted is not to be obtained, and I for one should be glad to avail myself of any scheme like the on $\epsilon$ I have suggested.

Dunstable

A. P. W.

\section{Sounding Flames}

IN the summer of $\mathrm{I} 842 \mathrm{I}$ attended the lectures of Dr. William Reid, brother of Dr. David Boswell Reid, the celebrated ventilator of the House of Commons, in the great barn-like classrooms of the latter chemist. In the practical class we produced sonorous flame vibrations in iron tubes three or four inches in diameter and about $2 \mathrm{ft}$. long, held over similar tubes covered with wire gauze. These instruments were the property of Dr. D. B. Reid, and produced a noise like the roar of a lion.
Edinburgh, Aug. 7
T. STRETHILL WRIGHT

\section{THE FRENCH ASSOCIATION FIOR THE AD.} VANCEMENT OF SCIENCE

THIS Association, as we have already intimated, meets at Lille on Aug. 20, and thus its meetings will be held contemporaneously with those of the British Association; this is perhaps to be regretted, as some of the members of the two Associations might wish to attend the meetings of both. The Lille session promises to be as brilliant as either of the two preceding ones. The proximity of Lille to Paris is very likely to attract a greater number of members than was gathered at Bordeaux or Lyons. A considerable number of foreigners have promised to "assist" at this year's meetiny ; among whom we notice the names of Prof. Sylvester and Dr. Odling.

The session will be opened at three o'clock on the afternoon of the 2oth, by the inaugural address of $\mathrm{M}$. Wurtz, the president for 1874, and also by an address by Lieut.Col. Laussedat, Professor at the Conservatoire des Arts et Métiers, general secretary of the Association for 1874 . There will, of course, be the usual sectional meetings, and several public lectures have been arranged for. Excursions always form an important part of the proceedings of the French Association, and three have been organised for this year ; the first excursion, on Aug. 23, will be to Boulogne ; the second on Aug. 25, to the coal-mines of the "Compagnie d'Anzin;" the third excursion commences on the 28th, after the conclusion of the meetings, and will probably be to Brussels and Anvers, lasting several days.

To show the magnitude to which this Association has already attained, we may state that about I50 names are down as readers of papers in the various sections, several of whom are to read more than one paper. M. Cornu is to describe a new optic spherometer. Several papers are to be read by M. Marcel Deprez on improvements in electrical apparatus and on certain theoretical aspects of steam-engines. Prof. Giard, of Lille, is to make several communications in Zoology, and $M$. Hamy in Anthropology; Prof. Houzeau, ot Rouen, is down for a paper on Concentrated Ozone ; and M. Lallemand, of Poitiers, will describe his researches relative to the Diffusion of Light. M. G. Lemoine will read two papers, one on 